FERMILAB-TM-1924

\title{
Preliminary Design Note for a Direct Coupled 200,000 Amp Neutrino Horn Power Supply with Energy Recovery
}

\author{
A.T. Visser \\ Fermi National Accelerator Laboratory \\ P.O. Box 500, Batavia, Illinois 60510
}

March 1995 


\section{Disclaimer}

This report was prepared as an account of work sponsored by an agency of the United States Government. Neither the United States Government nor any agency thereof, nor any of their employees, makes any warranty, express or implied, or assumes any legal liability or responsibility for the accuracy, completeness, or usefulness of any information, apparatus, product, or process disclosed, or represents that its use would not infringe privately owned rights. Reference herein to any specific commercial product, process, or service by trade name, trademark, manufacturer, or otherwise, does not necessarily constitute or imply its endorsement, recommendation, or favoring by the United States Government or any agency thereof. The views and opinions of authors expressed herein do not necessarily state or reflect those of the United States Government or any agency thereof. 


\section{Preliminary Design Note for a Direct Coupled 200,000 Amp Neutrino Horn Power Supply with Energy Recovery}




\section{TABLE OF CONTENTS}

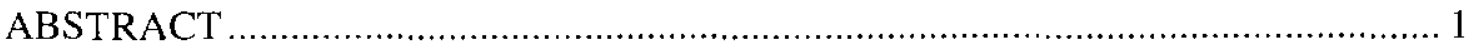

1.0 CIRCUIT DESIGN REQUIREMENTS AND CHOICES ............................... 1

2.0 EQUIVALENT HORN DISCHARGE CIRCUIT USED FOR ESTIMATES ........ 3

3.0 CALCULATIONS OF CIRCUIT PARAMETERS AND COMPONENTS .......... 5

3.1 Calculate the required discharge frequency for Fig. 1 ......................... 5

3.2 Calculate the required value $\mathrm{C}$ which yields $\mathrm{f}=96.3 \mathrm{~Hz}$ for Figure 1 .......6

3.3 Calculate the required capacitor charge voltage $\mathrm{V}$ which yields a peak current $\hat{1}=220,000 \mathrm{~A}$ into the horns.............................................. 6

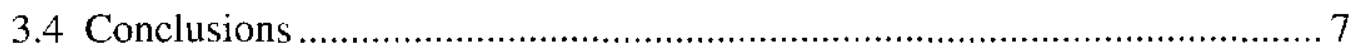

3.5 Calculation of the rms value of the horn current pulse train .................... 8

3.6 Estimated power losses caused by the pulse train ............................... 9

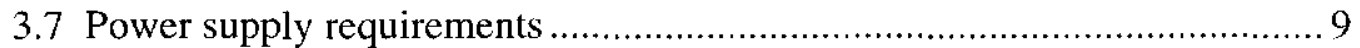

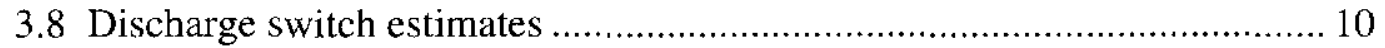

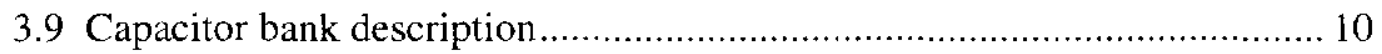

3.10 Rough system cost estimates (horns not included) ........................... 12

4.0 FINAL CONCLUSION AND COMMENT …................................................ 12 


\section{ABSTRACT}

The availability of high current, (several thousand amperes) silicon controlled rectifiers and high current, low loss capacitors make it practical to design a direct coupled energy discharge power supply for the neutrino horns in the proposed NuMI facility at Fermilab. The neutrino horns require a continuous pulse train of $200,000 \mathrm{~A}$ and $1 \mathrm{msec}$ duration at a pulse period of 1.5 seconds. This high current pulse train yields a system load current of about $9,000 \mathrm{~A}$ rms. Using a high power coupling transformer between the energy stored in a capacitor bank and the horns is very expensive because the transformer secondary winding would have to be rated for 9,000 A rms at about $1400 \mathrm{Vpk}$. The transformer would also add leakage inductance to the discharge circuit, take up a substantial amount of floor space and make stored energy recovery from the horns less effective or maybe even impractical. The transformer would need a reset winding to remove the high remnant magnet field in the transformer steel which is caused by the unipolar discharge pulses.

A coupling transformer is practical for high voltage loads, but the horns operate at a relatively low voltage of about $1400 \mathrm{~V}$, which makes direct coupling very attractive.

This note describes a preliminary design for a direct coupled system. From the design notes we can conclude that direct coupling is economical, practical, relatively simple, can use energy recovery and does not require materials or equipment that is hard to obtain. The charging power supply could be two standard (Fermilab) $240 \mathrm{~kW}$ beamline power supplies connected in series and grounded at the midpoint. The capacitor bank, switches, transmission line and controls can be most economically assembled in house. We may conclude that it is desirable to build a direct coupled neutrino horn power supply system and to connect both horns in series.

\subsection{CIRCUIT DESIGN REQUIREMENTS AND CHOICES}

The neutrino horns require a continuous dc current pulse train with a pulse period of $1.5 \mathrm{sec}$ and a peak value that does not change more than $10 \%$ during a beam spill duration of $1 \mathrm{msec}$. The minimum required peak current value during beam spill is $200,000 \mathrm{~A}$.

As a safety margin we will choose a peak current $\hat{1}$ that stays between $200,000 \mathrm{~A}$ and $220,000 \mathrm{~A}$ for a duration of $1.5 \mathrm{msec}$. The circuit used for the estimate is a basic LC damped discharge circuit (Fig. 1) which yields the required peak current when a switch releases stored energy from a charged capacitor bank to the horns. The horns are connected in series. A low inductance stripline connects the horns to the capacitor bank. The estimated circuit parameters are summarized below:

System Parameters

$\begin{array}{ll}\mathrm{R} & =5 \times 10^{-4} \text { Ohm (each horn) } \\ \mathrm{L} & =1.5 \times 10^{-6} \text { Henry (each horn) } \\ \hat{\mathrm{i}} & =200,000 \text { Amps minimum during } 1.5 \mathrm{msec} \\ \text { beam spill } & \\ \text { duration } & =1 \mathrm{msec} \\ \hat{\mathrm{l}} & \leq 10 \% \text { deviation during spill } \\ \text { pulse period } & =1.5 \text { seconds, continuous }\end{array}$


Estimated equipment distances are shown below:

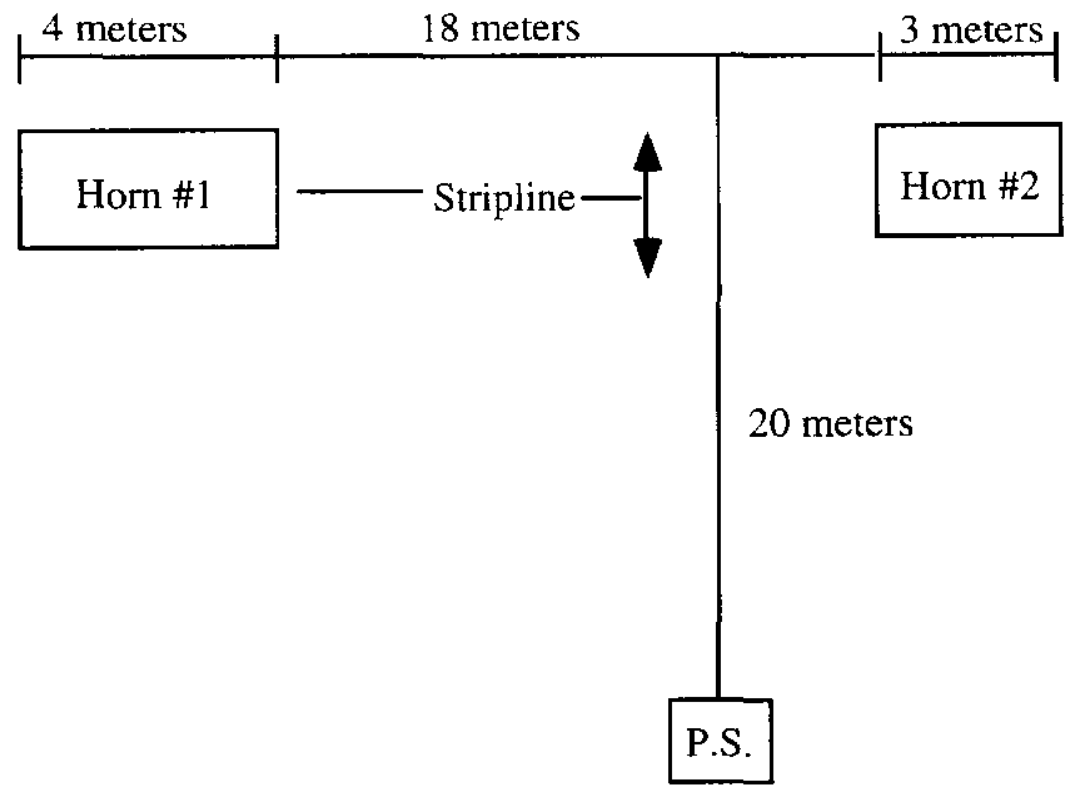

Summary of the neutrino horns circuit inductance $L$ and resistance $R$

\begin{tabular}{||l|l|l|l|l||}
\hline & & $\mathbf{L}$ & $\mathbf{R}$ & \\
\hline 1 & 2-horns & $3 \mu \mathrm{H}$ & $1 \mathrm{~m} \Omega$ & \\
\hline 2 & $\begin{array}{l}\text { transmission line } \\
\text { power supply to center of }\end{array}$ & & & \\
& $\begin{array}{l}\text { horns, 20 m } \\
\text { distance between horns, } 20 \mathrm{~m}\end{array}$ & $2 \mu \mathrm{H}$ & $0.247 \mathrm{~m} \Omega$ & \\
& power supply capacitor bank & $1 \mu \mathrm{H}^{*}$ & $0.03 \mathrm{~m} \Omega$ & Est.* \\
\hline 3 & TOTAL & & & \\
& & $\mathbf{8} \mu \mathbf{H}$ & $\mathbf{1 . 5 2 4} \mathbf{m} \Omega$ & \\
\hline
\end{tabular}




\subsection{EQUIVALENT HORN DISCHARGE CIRCUIT USED FOR ESTIMATES}

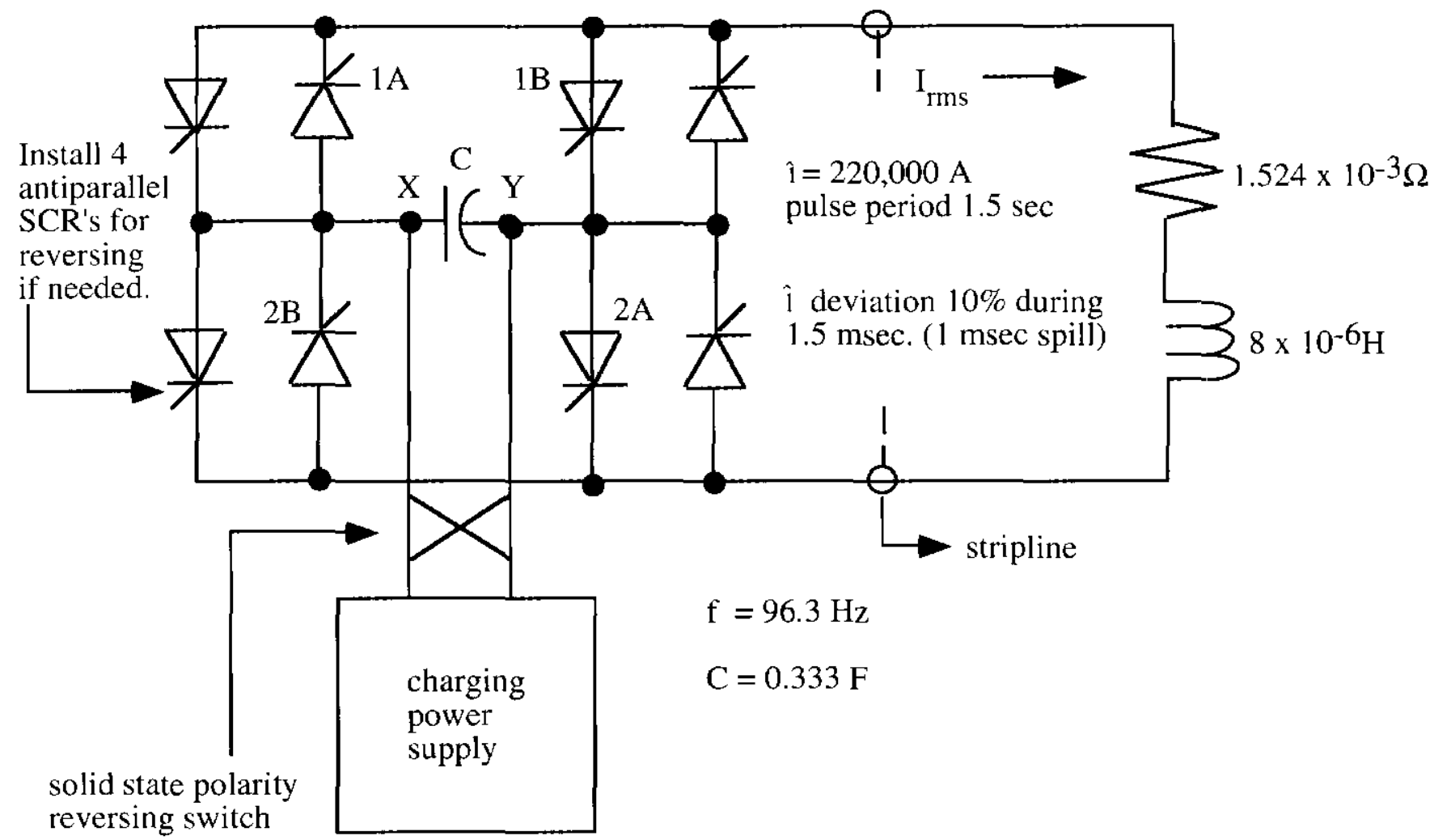

Figure 1. Basic horn discharge circuit with charge recovery

The equivalent circuit for the neutrino horns is shown in Fig. 1. Capacitor bank $\mathrm{C}$ is charged from a dc charging power supply via a charge polarity reversing switch, which initially charges bipolar capacitor $C$ positive at $X$. The charge at $C$ is released by firing all 4 SCR's $1 \mathrm{~A}$ through $2 \mathrm{~B}$. Only SCR 1A and 2A will stay on since SCR 1B and $2 \mathrm{~B}$ are reverse biased. $\mathrm{C}$ discharges now through the horns and some of the stored energy will be recaptured at $\mathrm{C}$ with $\mathrm{Y}$ being positive. This recovered charge direction is detected at the charge polarity reversing switch and charge will now be added to $\mathrm{C}$ at $\mathrm{Y}$ positive for the next pulse. Again, firing all discharge SCR's will now cause only discharge SCR 1B and 2B to carry the discharge current. The charge polarity at $C$ will thus change from pulse to pulse. This scheme yields the maximum amount of recovered charge and the lowest possible rms current values (lowest losses) in the discharge loop. Installation of antiparallel SCR's (Fig. 1) can yield horn current polarity reversal if needed. The capacitor bank and discharge SCR's need to be broken into possibly 8 sections to meet the component current ratings and capacitor case rupture energy ratings. The connections between the capacitor bank and horns can be made with a stripline as proposed in Fig. 2 . 


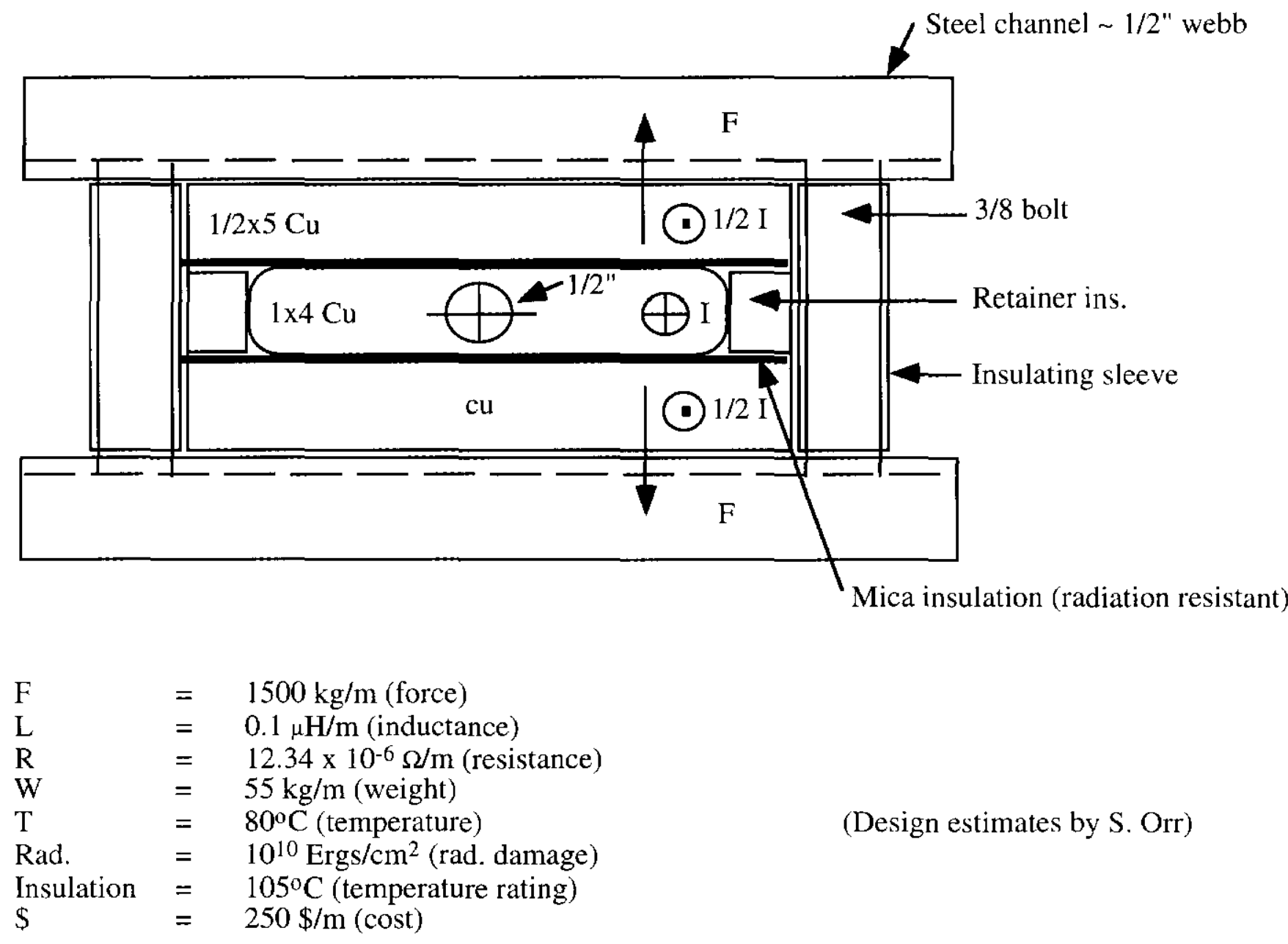

Figure 2. Watercooled stripline for neutrino horns

$$
\text { at } \hat{1}=220,000 \mathrm{~A} \text {. }
$$

From this circuit information and the required current pulses, we can estimate the operating frequency and component ratings. 


\subsection{CALCULATIONS OF CIRCUIT PARAMETERS AND COMPONENTS}

\subsection{Calculate the required discharge frequency for Fig. 1}

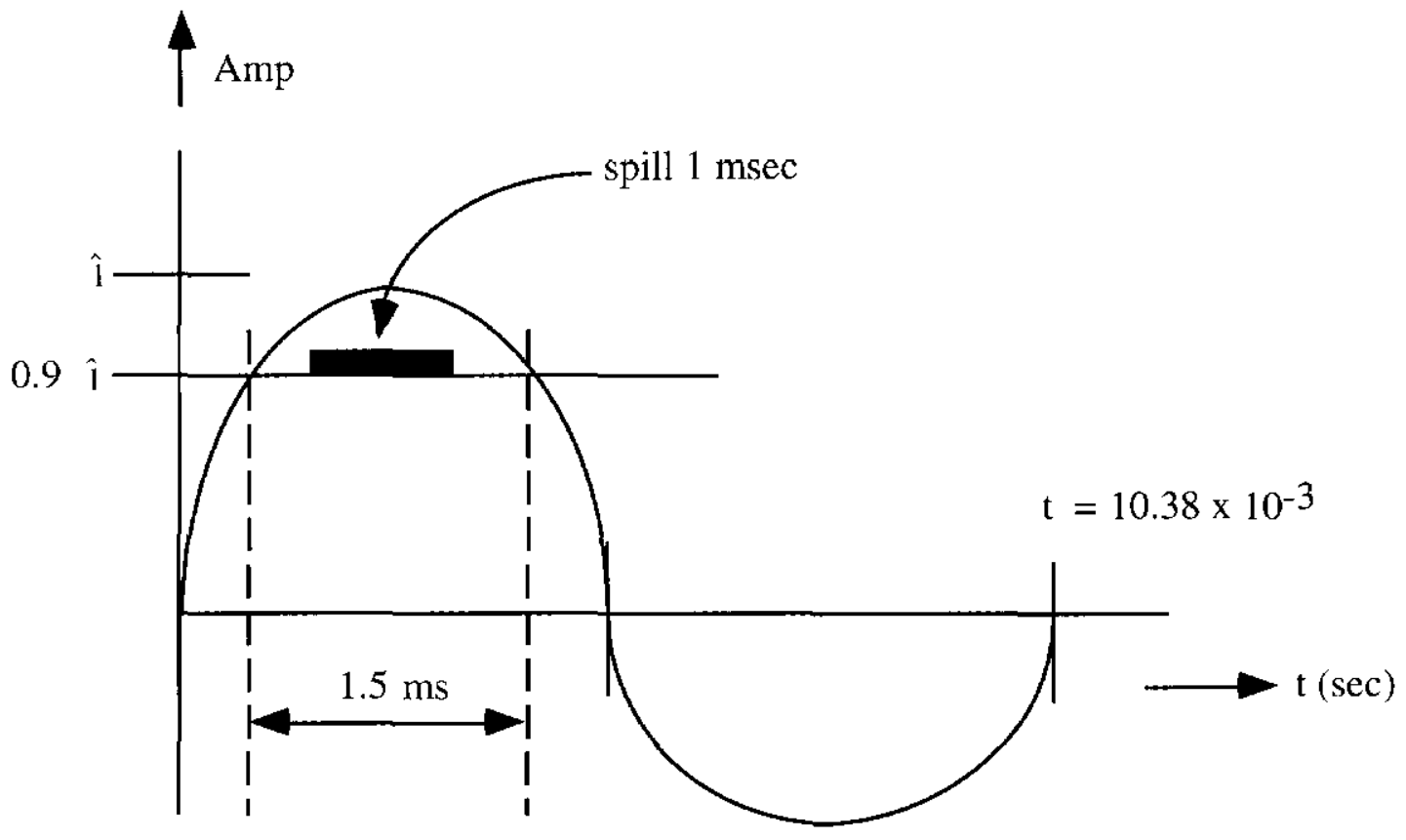

Figure 3. Discharge current of Figure 1.

$1.5 \mathrm{msec}$ equals $52^{\circ}$.

$\mathrm{t}=\frac{360}{52} \times 1.5=10.38 \times 10^{-3} \mathrm{sec}$.

$\mathrm{f}=\frac{1}{\mathrm{t}}=96.3 \mathrm{~Hz}$ 
3.2 Calculate the required value $\mathrm{C}$ which yields $\mathrm{f}=96.3 \mathrm{~Hz}$ for Figure 1 .

The ringing frequency of a damped oscillatory circuit is:

$$
\begin{aligned}
& \mathrm{f}=\frac{1}{2 \pi} \sqrt{\frac{1}{\mathrm{LC}}-\frac{\mathrm{R}^{2}}{4 \mathrm{~L}^{2}}} \\
& 96.3=\frac{1}{2 \pi} \sqrt{\frac{1}{8 \times 10^{-6} \mathrm{C}}-\frac{\left(1.524 \times 10^{-3}\right)^{2}}{4\left(8 \times 10^{-6}\right)^{2}}} \\
& 605=\sqrt{\frac{125 \times 10^{3}}{\mathrm{C}}-9.1 \times 10^{3}} \\
& 36.6=\frac{12.5}{\mathrm{C}}-0.91 \\
& \mathrm{C}=0.333 \mathrm{~F}
\end{aligned}
$$

\subsection{Calculate the required capacitor charge voltage $V$ which yields a peak current} $\hat{i}=220,000 \mathrm{~A}$ into the horns.

The instantaneous current value, $i$, in an oscillatory RLC circuit as in Fig. 1 is:

$$
i=2 \pi \mathrm{fCV} \mathrm{e} \mathrm{e}^{-\mathrm{Rt} / 2 \mathrm{~L}} \sin 2 \pi \mathrm{ft}
$$

$2 \pi \mathrm{fCV}$ is the undamped peak current value.

$\mathrm{e}^{-\mathrm{Rt} / 2 \mathrm{~L}}$ is the damping factor $(\delta)$.

$\sin 2 \pi \mathrm{ft}$ is the oscillatory function

$\mathrm{t}$ is time

The first peak current, $\hat{i}$, occurs at $1 / 4$ period.

$$
\hat{1}=2 \pi \mathrm{fCV} \mathrm{e}^{-\mathrm{R} / 8 \mathrm{Lf}}
$$




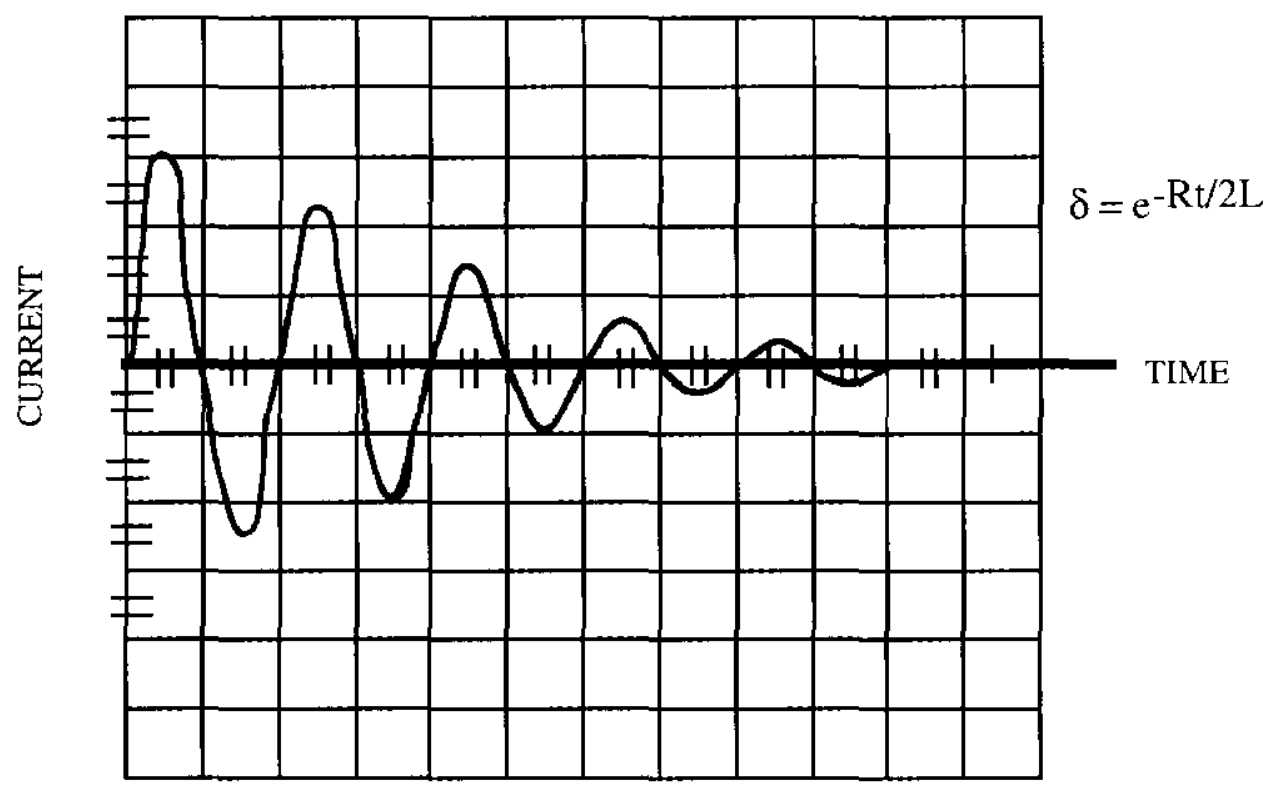

Figure 4: Damped oscillation of RLC circuit.

For Fig. 1: $\delta_{1 / 4}=\mathrm{e}^{-1.524 \times 10-3 / 8 \times 8 \times 10^{-6} \times 96.3}$

$$
\delta_{1 / 4}=e^{-0.247}=0.78
$$

The required charge voltage is:

$$
\begin{aligned}
& 220,000=2 \pi \times 96.3 \times 0.333 \times \mathrm{V} \times 0.78 \\
& \mathrm{~V}=1400 \mathrm{~V}
\end{aligned}
$$

\subsection{Conclusions}

A charge voltage of $1400 \mathrm{~V}$ into $0.33 \mathrm{~F}$ yields 220,000 A peak into the two horns connected in series.

The recovered charge voltage has a damping value of:

$$
\delta_{1 / 2}=0.6
$$

The recovered charge voltage $=850 \mathrm{~V}$. 


\subsection{Calculation of the rms value of the horn current pulse train}

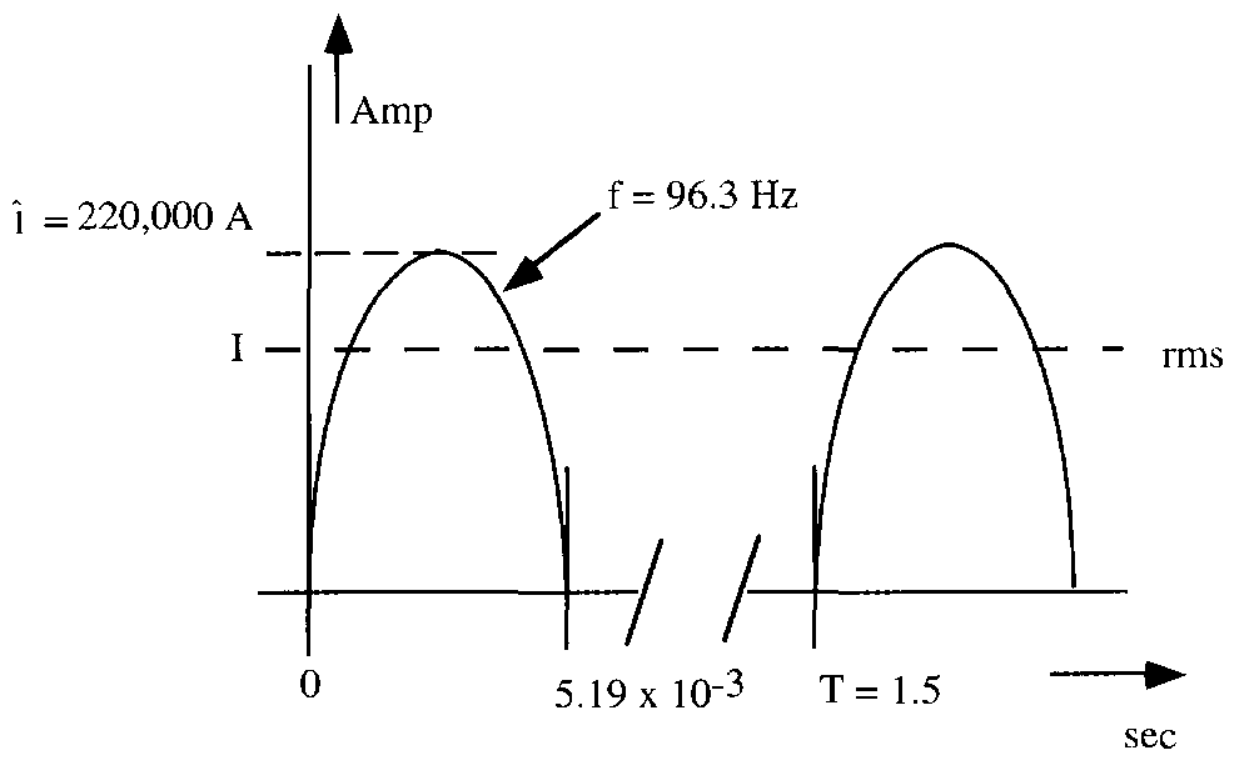

Figure 5. Continuous current pulses through the horns.

The rms value of the current pulse train, shown in Fig. 5, is the same as for the pulse train shown in Fig. 6.

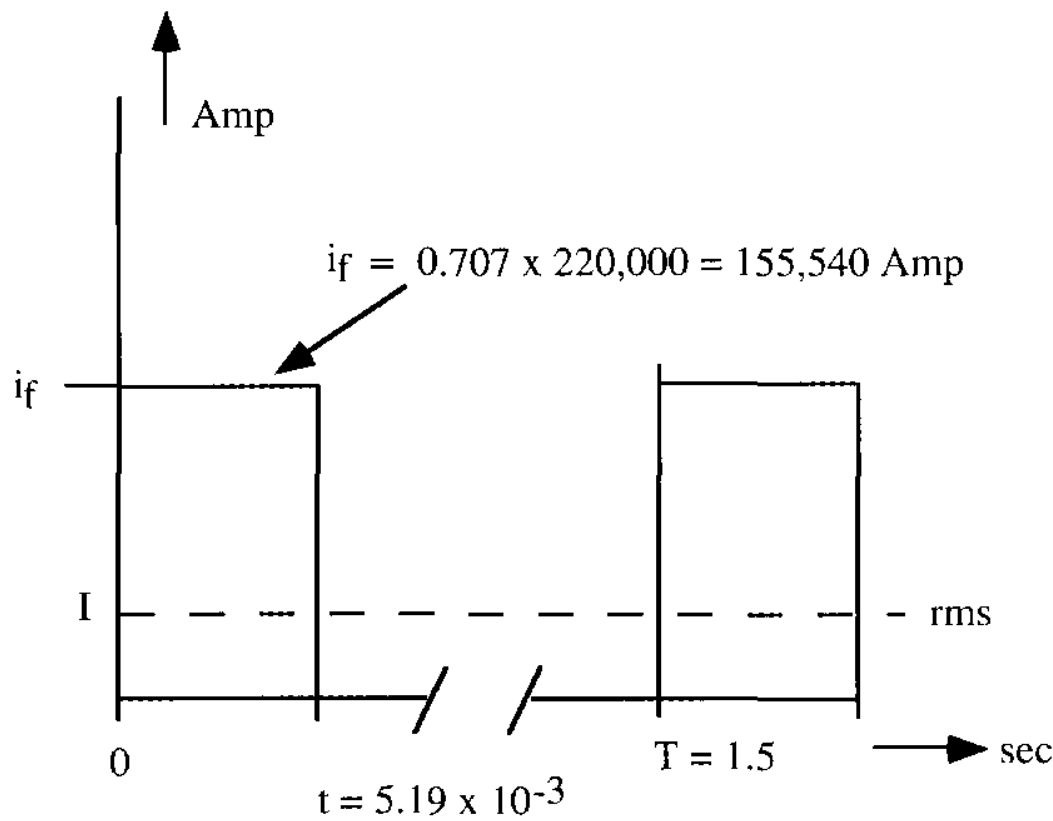

Figure 6: rms equivalent pulse train of Fig. 5. 


$$
\begin{aligned}
& I=i_{f} \sqrt{\frac{t}{T}} \\
& I=155,540 \sqrt{\frac{5.19 \times 10^{-3}}{1.5}}
\end{aligned}
$$

The rms value I of the current pulse train through the horns is:

$$
\mathrm{I}=9150 \mathrm{~A}
$$

\subsection{Estimated power losses caused by the pulse train}

$$
\mathrm{P}_{\text {loss }}=(9150)^{2} 1.524 \times 10^{-3}
$$

The estimated circuit power losses caused by the current pulse train are:

$$
\text { Ploss }_{\text {lo }}-128 \mathrm{~kW}
$$

The water cooling needed to remove $128 \mathrm{~kW}$ of losses is about 15 GPM.

\subsection{Power supply requirements}

The power supply ratings can now be estimated as below:

\begin{tabular}{|l|c|}
\hline power supply average output & $125 \mathrm{~kW}$ \\
\hline peak output voltage & $1400 \mathrm{Vdc}$ \\
\hline peak output current & $140.8 \mathrm{~A}$ \\
\hline recommended power supply rating & $200 \mathrm{~kW}$ \\
\hline
\end{tabular}

Estimate the required peak output current of the power supply as below:

Capacitor bank to be charged

Recovered charge voltage at start of charging

Final charge voltage

Choose to make up capacitor charge loss in
$333,000 \mu \mathrm{F}$

$850 \mathrm{Vdc}$

$1400 \mathrm{Vdc}$

$1.3 \mathrm{sec}$

The required charge current can be calculated from this information:

The required rate of charge voltage increase is $\frac{1400-850}{1.3}=423 \mathrm{~V} / \mathrm{sec}$ 
The charge current $\mathrm{i}=\frac{\mathrm{dQ}}{\mathrm{dt}}=\mathrm{C} \frac{\mathrm{dV}}{\mathrm{dt}}$ (constant current charging)

The required charging current $\mathrm{i}=0.333 \times 423=140.8 \mathrm{~A}$.

Conclusion: A constant charging current of $140.8 \mathrm{~A}$ and $1.3 \mathrm{sec}$ duration is enough to restore the capacitor bank charge to $1400 \mathrm{~V}$ after a discharge. Fermilab's $240 \mathrm{~kW}$ beamline power supplies can be set at $300 \mathrm{~A}, 800 \mathrm{~V}$. Two such power supplies in series would cover the required charging power supply rating. The center connection between the power supplies, or the connection between the horns, should be connected to ground. This ground point will keep the peak system voltage to ground to about $800 \mathrm{~V}$ or less.

\subsection{Discharge switch estimates}

The discharge SCR's (Fig. 1) need a more thorough investigation than the few comments below, but SCR GE\#C781LA looks reasonable.

$\begin{array}{ll}\text { SCR \#C781LA ratings: } & \text { Voltage : } 2100 \mathrm{~V} \text { (a little low) } \\ & \mathrm{I}_{\text {rms }}: 3925 \mathrm{~A} \\ & 1 \text { cycle } 60 \mathrm{~Hz} \text { surge non repetitive }: 45,000 \mathrm{~A}\end{array}$

The capacitor bank needs to be understood before a final SCR choice can be made. Let us choose to use 8 capacitor bank cells in parallel and thus 8 switches in parallel. The operating values/switch SCR are:

$\begin{array}{lll}\hat{\imath} & = & 27,500 \mathrm{~A} \\ \mathrm{~V} & = & 1400 \mathrm{~V} \\ \mathrm{I}_{\mathrm{rms} / \mathrm{SCR}} & =562 \mathrm{~A}\end{array}$

The estimated cost per switch including all heatsinks and clamps is:

$\operatorname{cost} /$ switch $=\$ 3,000 /$ switch or $\$ 6,000 /$ switch with reversing.

\subsection{Capacitor bank description}

The design of the capacitor bank is the most crucial. The capacitor bank supplies high current pulses and needs high rms current rated capacitors. Manufacturers should initially be contacted for recommendations about the proposed capacitor choice and the number of cells from which the total capacitor bank can be safely constructed. Other circuit components can be chosen to match the capacitor bank layout. 
The operating requirements for the capacitor bank are:

\begin{tabular}{||l|l|}
\hline capacitance & $333,000 \mu \mathrm{F}$ \\
\hline type & energy discharge \\
\hline discharge frequency & $100 \mathrm{~Hz}$ \\
\hline life expectancy & $\begin{array}{l}10^{7} \text { shots with } 95 \% \\
\text { survival? }\end{array}$ \\
\hline charge voltage & $1400 \mathrm{~V}$ \\
\hline reverse recovered voltage & $60 \%$ \\
\hline final reverse charge & $100 \%$ \\
\hline operation & bipolar \\
\hline peak discharge current & $220,000 \mathrm{~A}$ \\
\hline rms value of discharge current & $9000 \mathrm{~A}$ \\
\hline discharge pulse period & $1.5 \mathrm{sec}$ \\
\hline stored energy & $233 \mathrm{~kJ}$ oules \\
\hline capacitor case rupture energy & $*$ \\
\hline
\end{tabular}

*Needs to be known to find the number of capacitor cases that can be put safely in parallel.

Below are some estimates for the capacitor bank. A typical capacitor may be as follows:

$\begin{array}{lr}\text { stored energy: } & 2 \text { Joules/inch } \\ \text { weight: } & 0.03 \mathrm{lbs} / \mathrm{Joule} \\ \text { cost: } & \$ 2 / \mathrm{Joule}\end{array}$

The total capacitor bank of $330,000 \mu \mathrm{F}$ would be about:

\begin{tabular}{|c|c|}
\hline volume: & $\frac{233,000}{2} \sim 120,000$ inch $^{2}$ or $70 \mathrm{ft}^{3}$ \\
\hline final size: & $\begin{array}{l}\text { volume } \mathrm{x} \text { fill factor } \sim 140 \mathrm{ft}^{3} \text { or about } \\
8^{\prime} \mathrm{H} \times 12^{\prime} \mathrm{L} \times 1-1 / 2, \mathrm{D}\end{array}$ \\
\hline weight: & 7,000 lbs plus structural \\
\hline capacitor cost: & $\$ 660,000$ \\
\hline capacitor structural: & $\$ 40,000$ \\
\hline TOTAL CAPACITOR BANK: & $\$ 700,000$ \\
\hline
\end{tabular}

*A preliminary estimate supplied by GE, $1 / 11 / 94$, indicates a capacitor cost of $\$ 103,000$. 
3.10 Rough system cost estimates (horns not included)

\begin{tabular}{|c|c|c|}
\hline & & $\overline{\mathrm{K} \$}$ \\
\hline 1 & $\begin{array}{l}\text { power supply } 1400 \mathrm{~V}-200 \mathrm{~kW} \text { with } \\
\text { charge polarity switch }\end{array}$ & 125 \\
\hline 2 & $\begin{array}{l}\text { capacitor bank } 333,000 \mu \mathrm{F}, 2000 \mathrm{~V} \\
9150 \mathrm{~A} \mathrm{rms}\end{array}$ & $700 *$ \\
\hline 3 & $40 \mathrm{~m}$ transmission line water cooled & 15 \\
\hline 4 & 8 SCR switches (no reversing) & 24 \\
\hline 5 & 8 current XDTR's, 30,000 A (LEM) & 16 \\
\hline 6 & discharge resistor and safety system & 15 \\
\hline 7 & firing circuits and controls & 10 \\
\hline 8 & cables & 10 \\
\hline 9 & watercooling & 5 \\
\hline 10 & installation labor & 60 \\
\hline 11 & contingency & 20 \\
\hline & TOTAL: 1 MILLION DOLLARS & \\
\hline
\end{tabular}

*A preliminary estimate supplied by GE, $1 / 11 / 94$, indicates a capacitor cost of $\$ 103,000$.

\subsection{FINAL CONCLUSION AND COMMENT}

A system without a coupling transformer seems practical. A design using a transformer with a secondary winding rated $9150 \mathrm{~A} \mathrm{rms}, 220,000$ A peak at $1400 \mathrm{~V}$ peak will be very expensive. I do not know what it would cost. The transformer would add leakage inductance and resistance to the circuit. The losses would therefore be higher. Lowering the inductance of this preliminary design would reduce the cost.

General Electric Company supplied a preliminary capacitor cost estimate of $\$ 103,000$ compared to a capacitor cost estimate of $\$ 660,000$ shown in Section 3.9. The estimate supplied by General Electric is probably more realistic and indicates that the total system could be built for an estimated amount of $\$ 500,000$. 